\title{
Active Forms of Recreation in the Magazine “Nasze Zdroje” (1910-1914)
}

\begin{abstract}
The spa press at the beginning of the $\mathrm{XX}^{\text {th }}$ century often raised issues related to tourism, sport and recreation. The columnists appreciated the importance of health and the educational potential of active forms of spending free time. Activity was given an institutionalized character. This paper presents the active forms of recreation recommended to Polish society through their presentation in the magazine "Nasze Zdroje" (1910-1914). Hence, the article indicates the active forms of recreation available in the resorts such as mountain climbing, sports tourism, and skiing, as well as discussing the content popularizing mountain trips. Tips were given on how to prepare for this type of expedition, often combined with visiting historical monuments. Summer camps, including therapeutic camps, for children and adolescents were discussed, and were strongly promoted. Proposed recreational activities in the open air (walking, playing, and games) were presented, taking into account the educational aspect: instilling healthy habits in young people and adults.
\end{abstract}

Keywords: recreation, rest, health resort, “Nasze Zdroje” (1910-1914).

\section{Aktywne formy wypoczynku w czasopiśmie „Nasze Zdroje” (1910-1914)}

\begin{abstract}
Abstrakt
Prasa uzdrowiskowa na początku XX w. informowała czytelników o zagadnieniach związanych z turystyką, sportem i rekreacją. Publicyści doceniali znaczenie potencjału zdrowotnego i wychowawczego aktywnych form spędzania wolnego czasu. Aktywności starano się nadawać charakter zinstytucjonalizowany. W artykule przedstawiono takie właśnie sposoby wypoczynku zalecane społeczeństwu polskiemu

\footnotetext{
* Maria Curie Skłodowska University in Lublin, Institute of Pedagogy, Department of Methodology of Pedagogical Sciences.

Article Received: January 31, 2020; Accepted: March 20, 2020.
} 
poprzez ich prezentację na łamach czasopisma „Nasze Zdroje” (1910-1914). Stąd $\mathrm{w}$ artykule wskazano na aktywne formy wypoczynku dostępnego w kurortach poprzez uprawianie taternictwa, turystykę sportową, szczególnie narciarstwo, a także treści popularyzujące wycieczki górskie. Przedstawiono wskazówki dotyczące sposobu przygotowania się do tego rodzaju wypraw, łączonych zresztą często ze zwiedzaniem zabytków historycznych. Omówione zostały mocno promowane w piśmie kolonie letnie i lecznicze dla dzieci oraz młodzieży. Przedstawiono prezentowane w periodyku propozycje działań rekreacyjnych na świeżym powietrzu (piesze spacery, gry i zabawy) uwzględniające aspekt wychowawczy: wpojenia młodzieży i dorosłym nawyków prozdrowotnych.

Słowa kluczowe: rekreacja, wypoczynek, uzdrowisko, „Nasze Zdroje” (1910-1914).

\section{Introduction}

The balneological press at the beginning of the 20th century often raised issues related to tourism, sport and recreation, understanding the importance of the health and educational potential of the active leisure activities it promoted. Properly selected forms of spending free time have a significant impact on human health and well-being. Activities were give an organized and institutionalized character. Unfortunately, apart from autonomous Galicia, the partitioning powers did not agree to the existence of too many mass social organizations, seeing in them primarily a threat to the official policy of Russification or Germanization of the state.

This article presents, from an historical perspective, the features of active forms of recreation propagated in the pages of "Nasze Zdroje" (1910-1914) which may also be useful in the current debate on this topic. Looking for new solutions and reaching for new ideas to promote a healthy lifestyle, it is worth using the experience of the past; good, proven native models. The forms of recreation presented in the magazine are still used. The arguments used by journalists have not lost their relevance, they confirm the legitimacy of carrying out retrospective studies by researchers, with a view to the present and the future. When planning programmes for the promotion of active leisure activities tailored to the $21^{\text {st }}$ century, it is worth trying to extract those elements that have proven themselves in the past, influencing the progress in the popularization of active forms of recreation in the early twentieth century. The key to success is still the same - instilling in young people and adults habits related to the protection of their own health through active recreation, and the involvement of hygienists, doctors, journalists, representatives of tourism and sightseeing societies, as well as celebrities, today. Understanding that the very possibility of practising performance sport has remained exclusive to the elite, propagating pro-health patterns to a wide range of readers may give birth to an increased following (Klimek 1910: 4). 
The aim of this article is to present active forms of recreation recommended to Polish society through the magazine "Nasze Zdroje" (1910-1914). The main task set by the publishers and editors of this magazine was to encourage readers to engage in spa tourism, and convince potential patients about the advantages of native spas. The editors emphasized the possibility of acquaintance with active forms of recreation available in the resorts during time free from treatments, and with the broadly understood spa culture, promoting the health qualities of famous and less known places. The promotion mainly covered spas located in Galicia and Bukowina, the Eastern Borderlands and the Kingdom of Poland. The effectiveness of these activities can be confirmed by the recognition of "Nasze Zdroje" as its own press organ by the Tourism Section of the National Association of Spas and Health Resorts, the Carpathian Skiing Society, and the Academic Tourism Club in Lviv. The presentation in this magazine of the Polish spa industry in the widest territorial scope of the former lands of the Republic of Poland, from the Polish-Lithuanian coastal resort of Palanga, to the Carpathians, trying to disseminate knowledge in substantive articles as well as correspondence, descriptions and even illustrations, was significant. The issues of the organization of tourism were discussed in the journal, especially the importance of tourism as one of the main means of physical education next to gymnastics, sports and games (Wiadomości bieżq̨ce 1911b: 311; Bednarz-Grzybek 2018: 141). To reach potential patients directly, the National Association of Spas and Health Resorts (1910) organized a series of lectures that the press reported and commented on. Particular emphasis was placed in this campaign on mobilizing those lands in which the greatest indifference and lack of awareness was found, i.e. in the lands around Kiev, Ukraine, Podolia and Volhynia ( $Z$ nowym rokiem 1913: 1). In this way, efforts were made to make the public aware of the value and richness of the Galician spas in terms of healing and health, as well as the beauty of nature and the variety of forms of active recreation offered.

Before discussing the forms of recreation presented in "Nasze Zdroje", it is worth familiarizing readers with the magazine itself. The publisher of "Nasze Zdroje" (1910-1914), who was also the editor, was Juliusz Bandrowski, a longtime collaborator with many Lviv, Krakow and Warsaw magazines. Earlier, he had edited "Zdrój Ciechociński" (1907-1910) and contributed to the popularization of Ciechocinek as a health resort. The magazine was published as a weekly in the season (from May 15 to September 15), while out of season (from September 15 to May 15) it was published once a month. From the fourth issue of 1913, it had a slightly modified title "Nasze Zdroje i Nasza Turystyka". At that time, there also appeared a related supplement entitled "Nasza Turystyka" (1913-1914). The editors of "Nasza Turystyka" were: Stanisław Zachariasiewicz and Mieczysław Orłowicz (Bednarz-Grzybek 2018: 104). The magazine was an opening for Polish tourist societies. "Nasze Zdroje i Nasza Turystyka" ceased to be published when the first issue of the new journal "Zdrojownictwo i Turystyka" appeared (April 1, 1914). 


\section{Active forms of recreation from the perspective of "Nasze Zdroje"}

On the pages of "Nasze Zdroje", the activity of the Warsaw Touring Society and its provincial branches in the Kingdom of Poland, thanks to which thousands of tourists undertook annual trips around the lands of the former Polish-Lithuanian Commonwealth, were praised. In 1911, 7,000 people took part in the Society's events, "scattering widely within the borders of the motherland from Morskie Oko to Kashubia". The journal encouraged participation in subsequent trips by publishing photos of the most beautiful views of the Polish landscape taken during the expeditions (Wiadomości bieżące 1912c: 93; cf. Jarosiński 1910a: 94-95; Jarosiński 1910b: 180-181). Established in 1906, the Polish Touring Society in the Russian Partition organized recreational and sporting trips, focused on learning about the architecture, history and specific qualities of a given place. They visited battlefields, castle ruins and museums full of national memorabilia. It was possible to get to know the flora and fauna of a given region, its geological structure or an interesting natural phenomenon. Similarly to the Tatra Society, the Polish Touring Society allowed its members and guests to obtain travel discounts and cheaper admission tickets to visited facilities (Polskie Towarzystwo Krajoznawcze 1913: 21-22). So, we were dealing with institutional activities aimed at awakening an interest in one's own country, through a wide range of activities from organizing trips, through appropriate guidebooks and advertising publications to activities that practically facilitate sightseeing.

Vacation trips to spas should be included amongst the oldest forms of tourism. Spas that offered sulphur baths became particularly popular because of the healing effects of this water on the skin. The magazine described them and encouraged visits (Kubik 1912a: 115-116; Kubik 1912b: 136-137). Henryk Gąsiorowski (1911) used highly patriotic advertising of the mountains on his countrymen. He appealed for the development of a modest rail network and the creation of a greater number of hostels and tourist manor houses that would allow a larger group of patients to take advantage of the country's possibilities. According to him, an example of neglect was Worochta, which, although it had been known for a long time as a place of climatic summer treatment, also had the potential to become the most visited winter spa in the eastern part of the country (Gąsiorowski 1911: 2-3). However, this required some of the effort and expense which had been borne by other popular towns, especially Zakopane, Lubień, Krynica, Szczawnica, Rymanów, Busk and Solec (Górski 1910: 149). Often the solution to this problem was the establishment of an institution at the local level, e.g. Truskavets was advertised, where social life for patients was organized by the Truskavets Club. It initiated trips, festivals, anniversaries, reunions, concerts and theatre performances (Espe 1911: 71). Inowłódz, apart from beautiful nature, also offered various types of entertainment provided by local institutions. These included: playing tennis, 
Sunday reunions, boat rides on the Pilica, and horse and carriage trips to the surroundings of Rzeczyca and Studzianna (G.K. 1911: 235-236).

In "Nasze Zdroje" in 1912 it was written that poor Galicia had great wealth in its healing sources. The benefits that could flow from skilfully directing masses of patients towards the charming corners of the Carpathian and Tatra Mountains were emphasized (Nasz Przewodnik po zdrojowiskach, miejscach klimatycznych i turystycznych 1912). Good practice was pointed out; for example, by writing about high tourist traffic in the Silesian Beskids. It was written that there was no part of the Carpathians visited by as many tourists as that region, although it was regrettable that the vast majority were Germans. Poles, despite the proximity of Krakow, in which several tourist societies operated, rarely visited the mountains. To revive the Polish tourist movement, the "Beskid" Society was established in Cieszyn (1910) - as "Nasze Zdroje" reported hopefully (Przegląd zdrojowisk i uzdrowisk polskich 1912b: 311-312; O kulturę ślaskich Beskidów 1914: 184). In popularizing tourism, there were also calls for the modernization of 'base camps', which could provide a place for dignified rest (W.F. 1912: 184).

When advertising trips to health resorts and physical activity, the press did not forget about the youngest: for children it recommended Rabka above all (Kolonie lecznicze polskie 1910: 150; cf. Łazarski 1912: 219). It was noted that the attendance of children at spas, however, imposed additional obligations on the resort management. It was necessary not only to make their stay more pleasant, to care for them, but also to organize their time in such a way that their fun, presence and noise would not disturb other patients. The vital interest of the spa came into consideration here, all the more so because the patients coming to the spa were mostly, sick, nervous, so they could not be indifferent to "racing crowds, screams, or worse, the mocking of disability", which could happen (Lazarski 1912 : 219). So that the spa would not lose its guests, Tadeusz Łazarski (1912) proposed, for example, a separation of parts of the spa estate from each other, designating a suitable section for each group. A part shaded with trees, but not devoid of sun and air, not too distant from the centre, full of comfortable benches, where spa life would focus, was recommended for patients seeking respite and peace. However, a further, separate and more secluded part should be organized into a space dedicated to games for children, adolescents or adults who would look for a little more active, and thus slightly louder forms of activity (ibidem).

It is worth recalling that games and activities, as children's preferred forms of spending free time in the spa, and elsewhere, were first formed in the English practice of physical education, and because of their significant educational values, quickly spread to Europe. They were not only a means of developing physical fitness, but also allowed the shaping of desired character traits, especially the ability to cooperate and abide by the rules, perseverance and determination. The educator Thomas Arnold drew attention to these educational values. The physical activity of young people, following the example of English Scouts, was additionally 
associated with expanding knowledge of nature through various types of youth camps, trips and field activities, which was eagerly emphasized in "Nasze Zdroje". Scouting quickly gained recognition as a universal youth educational organization, it was brought to Polish soil in 1911, under the native name 'harcerstwa' (Wiadomości bieżące 1913b: 164).

Henryk Jordan, who organized a playground called Jordan Park in the 8-hectares of Błonia Krakowskie, played a special role in the development of youth physical recreation. His initiative had a great impact on the perception of the extracurricular education and recreation of children and youths in Poland. From then on, play meant carefree spending of free time on any activity that pleased the child. Games, on the other hand, were a kind of activity done according to predetermined rules. Children had the opportunity to use gymnastic equipment, to play with building blocks, play football, or socialize. There was no shortage of those willing to take advantage of this form of spending free time. Efforts were also made to provide young people with more traditional entertainment, for example, "Nasze Zdroje" reported about children's tea-dances organized under the direction of Helena Kuczalska (Przegląd zdrojowisk i uzdrowisk polskich 1910: 125). In 1910, entertainment of this type took place twice a week, on Mondays and Thursdays (M.R. 1911: 10).

The journal was pleased to report the increased tourist traffic in Galicia, supported mainly by high school and university students. Youth trips to spas were popularized, for example by describing the trip of 21 middle school students from Jarosław, under the direction of Józef Ekkert and Zygmunt Wojtanowicz, to Iwonicz and Rymanów (J.E. 1912: 207-208). The young people were very hospitably received by the owner of the institution in Rymanów, Count Jan Potocki, visited the spa and became acquainted with the healing effects of its sources.

During a stay in a health resort as a cure or on a tourist trip, active resting adapted to the possibilities and state of health, e.g. gymnastics, walking, various games, was always recommended. In "Nasze Zdroje", an example of a treatment facility in Ojców was cited, where doctors observed that symptoms of depression or frequent headaches disappeared under the influence of physical activity, and were replaced by: a sense of energy, willingness to move, and enthusiasm of patients for new forms of activity, such as gymnastics in the open air (Kozłowski 1912: 119). Patients staying in the spa in Ojców, therefore, had to attend gymnastics every day at 7 am. Only the doctor could allow exemptions from the exercises. Gymnastics took place on a sports field, on a levelled square, covered with beautiful grass and surrounded by bushes. The exercises were led by a doctor, and their duration ranged from half an hour to three quarters of an hour. Gymnastics for women was managed by a qualified gymnast, their exercises started at 9 am. The article reminded readers about the proper gymnastic attire, it was also emphasized that this type of activity has a positive effect on the metabolism. Similar activity was also 
promoted in Palanga and the Roman Skowronski Mechanotherapeutic Facility in Warsaw (Szczepański 1911: 163).

Every movement and physical activity, not only in the form of gymnastics, was recommended as one of the therapeutic factors available at spas. Patients were required to take walks and horse rides, always adapted to their health conditions (Dr K.K. 1911: 78). They were encouraged to spend their free time outdoors, surrounded by the unusual nature and the specific microclimate of spa facilities. People in a weaker condition were advised not to overdo physical exertion and to choose places for walks equipped with benches to rest. A particular feature of the spas was the outdoor paths, marked out in parks or forests, located near the spa town, marked and divided into categories related to the degree of difficulty and time necessary for their passage (Orłowicz 1913b: 6-7).

Another way to encourage patients to move outdoors and to exercise was to advertise organized trips, often along accessible walking routes, indicating historically important places that were worth visiting. The Galician Cyclists' Association and the Academic Tourist Club organized trips to the Kingdom of Poland, and Lithuania, and mountain expeditions, usually to the Tatra Mountains (Akademicki Klub Turystyczny we Lwowie 1911: 81; Wiadomości bieżące 1911a: 123). People travelled far and wide not only with a view to rest or get treatment in a specific place. The purpose of the trips was also to learn about new places, customs, culture and the way of life of others. Trips were a variation to the monotony, a generally restful stay in a spa or summer resort. Organized often on the occasion of anniversaries of various historical events, they also allowed a deepening of knowledge in this area.

Travel organizers were required to make their trips safe, taking special care on mountain trips. That is why the leaders of the Ski Section of the Academic Sports Association in Krakow organized special courses for fans of this type of trip, taking care of the proper physical and mental preparation of tourists (Wiadomości bieżqce 1913c: 38-39; Z ruchu towarzystw 1913: 1-4; Kronika turystyczna 1914: 2). The courses in Zakopane, organized under the supervision of the educator Henryk Bobkowski were widely discussed. The ski lessons were to last four days (December 25-28). The time from December 29 to January 1 was to be used for ski trips in the Tatra Mountains (Kronika turystyczna 1914: 2). Finally, for the sake of safety, the licensing of mountain guides was introduced (Akademicki Klub Turystyczny we Lwowie 1913a: 70-71; Kronika turystyczna 1913: 34; Wiadomości bieżące 1913c: 38-39; Z życia towarzystw 1913c: 15).

Trips by doctors to spas, which were organized by the National Association of Spas and Health Resorts, were a specific form of tourism combining active leisure with the acquisition of knowledge. Such visits took place to Rabka, Zakopane, Szczawnica, Żegiestów, Krynica, Iwonicz and Rymanów (Orłowicz 1912: 231-232; Nasza turystyka 1912: 218-219; Wiadomości bieżace 1912d: 166). The Association cooperated with the Tourist Association in Krakow in the field of tourism 
promotion, thanks to which the Association of Spas managed to create a special Tourist Section (1912). The purpose of its operation was to intensify tourist traffic to Polish spas and their surroundings, to create favourable conditions for winter sports, and to awaken the passion and respect for natural beauty in society (Krajowy Związek Zdrojowisk i Uzdrowisk 1912: 191; Sekcja turystyczna Krajowego Związku Zdrojowisk i Uzdrowisk 1912: 163). Promotion of active leisure, and educational activities, was also carried out, stigmatizing littering on paths and leaving a mess in shelters. As well as the mountains, trips connected with visiting historical monuments such as the castles in Olesko and Podhorce, walls in Melsztyn, Czorsztyn, Tenczyn, and synagogues in Bełz, Żółkiew, and Kamionka Strumiłowa enjoyed growing popularity. As a result, tourists began to appear, especially in the mountains, who did not limit themselves to visiting the Tatras, the Pieniny, Babia Góra, and Czarnohora, but wandered throughout the entire Beskids, not even climbing the Gorgan peaks (Polskie Towarzystwo Krajoznawcze we Lwowie 1912: 143; Bednarz-Grzybek 2018: 664-666).

In "Nasze Zdroje" this particular form of tourism was widely discussed. The idea of a special association dealing with the promotion of mountain tourism was presented by Adolf Tetmajer in the 1870s, and in 1873 the Tatra Society was created. Its establishment was possible thanks to the autonomy of the territories located within the Austro-Hungarian monarchy, enabling the formation of Polish organizations and associations. This year can, therefore, be considered the beginning of organized mountain tourism, especially since the creation of local branches of the Tatra Society was also allowed. For the first period of its existence it was called the Galician Tatra Society. Initially, the seat of the Society was Nowy Targ, in 1874 briefly Zakopane, and then Krakow. In 1912, the Tatra Protection Section and the Volunteer Mountain Guard were created, the predecessor of today's Tatra Volunteer Rescue Service (Wiadomości bieżące 1912b: 76; Bednarz-Grzybek 2018: 461). The purpose of the Society was to organize mountain stays and hikes for mountain lovers. Construction of shelters and tourist stations and the marking of routes in the Tatra Mountains began. The Tatra Society also spoke about the development of Zakopane as a health resort that could become the basis for the development of Tatra tourism. The range of trips available in the spa resorts became more and more attractive. In "Nasze Zdroje" and "Nasza Turystyka" - a supplement to "Nasze Zdroje", the length of time needed, necessary equipment, fees, information about guides and organizers, as well as assessments of the organizers by participants were presented in great detail (Kronika turystyczna 1913b: 30; W.A. 1913: 29).

The popularization of tourism in the second half of the nineteenth century resulted in the appearance of another variant - sports tourism (Hemmerling 1911: 317). Like mountain-climbing, it required physical fitness and mental resilience. One man particularly important in its development in Poland was Mieczysław Orłowicz, the founder and president of the Academic Tourist Club, one of the 
largest Polish tourist organizations, which in the years 1908-1910 was a section of the Academic Sports Association (Orłowicz 1913a: 39-41). At the beginning of the 20th century, skiing proved to be a particularly popular branch of sports tourism. The Carpathian Ski Association in Lviv (1907), which focused its attention on the popularization of winter sports, contributed significantly to its development. Ski training courses were regularly organized, joint trips, races and ski competitions were organized. Similar activities involving the promotion of skiing and winter tourism were conducted by the Zakopane Branch of the Tatra Ski Society, later renamed the Ski Section of the Tatra Society (Wiadomości bieżqce 1912a: 8; Związek Polskich Towarzystw Turystycznych 1913: 32). Health and fitness values were associated with skiing (Rak 2010: 11).

The development of skiing was associated with the overall development of the sports movement in the 19th century. According to Leopold Świerz, the motive for interest in skiing was to practice winter tourism on a larger scale. On the other hand, in the opinion of Zenobiusz Pręgowski and Stanisław Zaborniak, the popularization activities of Lviv skiers had a decisive impact on the development of Polish skiing. Regardless of the reasons for the fascination with this sport, the spread of skiing among young people was desirable. On the one hand, interest and publications on this topic fuelled the idea of the physical revival of the nation, which crystallized in Poland in the nineteenth century in the organized forms of activity of the "Sokol" Gymnastic Society and the Tatra Society - on the other, there were claims that skiing was an activity that one can do for pleasure. Józef Schnaider drew attention to this somewhat hedonistic motive in 1898. In a similar vein, Roman Kordys and Eugeniusz Piasecki wrote about the aesthetic impressions that accompany ski tourism and about the entertainment value of this sport (ibidem: 14; Bednarz-Grzybek 2018: 457-462). In "Nasze Zdroje", however, the health and educational value of skiing, as well as all other outdoor activities, was most often emphasized. For the pioneers of Polish skiing, the pleasure of skiing in the winter, especially in mountainous areas, was an important motive for choosing this sport, something which can be found in the descriptions of this type of trip published in "Nasze Zdroje". They express the admiration for the beauty of the mountains, the aesthetic impressions and the pleasure that the participants derived from them.

The emergence of the theme of competition in ski tourism was associated with newly formed ski organizations, including the Ski Section of the Academic Sports Association (1909), the Tatra Ski Association in Krakow (1910), and the Ski Section of the Academic Tourist Club (1910), which began to organize competitions. Extensive coverage of the competitions appeared in the pages of "Nasze Zdroje", there was information about inter-club skiing competitions on Kalatówki on January 1, 1913 (Wiadomości bieżące 1913a: 14; Wiadomości bieżące 1913b: 25; Z życia towarzystw 1913a: 11), and also about the competition in Slavsk on March 2, 1913 (Zawody narciarskie w Sławsku 1913: 12). "Nasza Turystyka” presented the programme of international sports competitions in Zakopane during the Easter 
holidays of 1913, organized by the Tatra Ski Society in Krakow. They included six runs in skiing disciplines, and also tobogganing competitions were planned, however they did not take place due to the lack of snow on the road from Cyrhla to Jaszczurówka (Kronika turystyczna 1913a: 12; Zawody Tatrzańskiego Towarzystwa Narciarzy 1913: 15). The competition contributed both to the popularization of recreational and leisure activities of this form, and to the professionalization of skiing as a winter sport. These activities informed readers of the magazine about the multifaceted impact of skiing on the areas of human life and health. They were used to promote both skiing and broadly understood physical culture. Combining sports activities with tourism also characterized the activities of the Krakow Automobile Club, which organized trips mainly to the Tatras and Pieniny, also reported on. Trips to the Tatra Mountains were also organized by the Galician Cyclists' Society. However, the Touring Society, founded in 1913, made the greatest contribution to the intensification of tourism activities (Wiadomości bieżace 1913a: 95).

Representatives of wealthy social strata had no problem choosing the place and time for a tourist trip. Representatives of the less-well-off circles chose the offers they could afford (Olkuśnik 2015: 12-13). When popularizing spas, the importance of the summer was not forgotten. For example a summer resort in Anin near Warsaw was mentioned in "Nasze Zdroje"; located in the Wawer forests of Count Branicki, and praised for the modernization carried out by the Friends of Anin Society. In order to provide active forms of spending free time for guests, it was decided to establish a park there, providing vacationers with suitable health conditions (Wiadomości bieżące 1912g: 316). A summer resort in Puszczykowo near Poznan was also promoted in the press, recognizing that every major city should have such leisure facilities nearby for its poorer residents. For example, information was provided about a place near Kalisz, in an area acquired by the doctors Bronisław Koszutski and Emilia Piotrowska-Orgelbrand, with a garden adapted for sunbathing, air bathing, a gym and team games (Przegląd zdrojowisk $i$ uzdrowisk polskich 1912a: 207; Wiadomości bieżące 1912e: 275; Wiadomości bieżące 1913c: 40; Bandrowski 1910: 204-205).

When presenting the range of spas and summer resorts worth recommending to readers, attention was drawn to the problem of organization and travel costs, and the urgent need to adapt the transport infrastructure to the requirements of tourists was noted (Jak stworzyć ruch turystyczno-krajoznawczy w Galicji 1912: 23-24; Z nowym rokiem pracy 1913: 1). At the end of the nineteenth century, suggestions appeared also to enable residents to use forms of active recreation in the cities themselves. The rapid processes of industrialization and urbanization had gradually changed cities into a space unfriendly to humans, a crowded space, noisy and suffocating everything living thing with the thick smog of industrial plants. The buildings of a capitalist profit-oriented city, characterized by crowded tenements, and a lack of hygiene facilities, water supply and sewage systems, forced its 
inhabitants - particularly children, to look for various forms of movement by using all free spaces for games, playing, and walks (Orłowicz 1913b : 6-7).

The journal encouraged city dwellers to take part in various types of outdoor recreational activities, the only form of physical activity available to them. It was suggested that playgrounds be created, using all green areas as a place of mass rest and recreation. Tourist associations, societies and sports clubs activated enthusiasts of selected fields of sport and tourism. In addition to aristocratic and bourgeois associations, the first workers' clubs and associations began to form (Z życia towarzystw 1913d: 42). Trips organized by them were particularly popular, e.g. the expedition to the castles in Olesko and Pidhirtsi described in "Nasze Zdroje" on May 5, 1912 (Wiadomości bieżące 1912d: 167).

The journalists of "Nasze Zdroje" were aware of the limited possibilities for part of society to leave for a resort or pay for an organized trip. Apart from financial problems, the decisive issue was the free time and organizational possibilities of the families. It was recommended, however, to take children out of the city, even for short summer camps organized in the countryside, in peace and quiet with unlimited access to fresh air and greenery. The need to temporarily leave noisy urban environments was recognized. Departure in the summer from the city - even for a few weeks - had become an undeniable necessity for people locked in the conditions of urban life (Kęczkowska 1912: 202-203). According to the columnists, the cost of travelling to the near or distant countryside should be one of the most important and necessary budget items for people from all spheres. The possibility of institutional support in this area was analysed. "Nasze Zdroje" presented a summer camp in Podsobień on the estate of Count Krasicki, commenting on its good organization, confirmed by statistics from its four years of existence: in 1909 it had 65 participants, in 1911, 72, and in 1912 over 100 (Wiadomości bieżace 1912g: 316). Several times, the holiday camp in Huta Korostowska, maintained by the Polish Pedagogical Society, was mentioned in the publication. In 1911, 81 boys were admitted to stay, including 38 high school students and 43 folk high school students, recruited from the poor, those most in need of help. The head of the camp was Michał Mucha, and his work was supported by teachers Karol Jaremko, Michał Kornecki, Alojzy Góralski and Józef Kobylański. In 1912, the Society again sent about 80 boys to this camp. There was also mention of the holiday camp for students organized in Poręba Wielka (Wiadomości bieżące, 1912f: 302). The landowners receiving the children organized a holiday for them with great enthusiasm. They provided them with various types of attractions, including games and fun. Thanks to this, holidays in the bosom of nature, recreation, and contact with nature could be shared by workers' children. Unfortunately, the need exceeded Galicia's capabilities - which the journalists regretted. Many poor young people were deprived of the opportunity to enjoy the benefits of this type of institution for financial reasons (W sprawie kolonii wakacyjnych 1912: 194); (Sokołowski 1913: 205). It was written in "Nasze Zdroje" that the Summer Camp 
Societies in the Kingdom of Poland, Lithuania and Poznan were developing more lively campaigns than in Galicia (Wiadomości bieżące 1913d: 91). There was a demand for social support for the organization of summer camps influencing the harmonious development of Polish youth.

\section{Conclusion}

The phenomena of the development of mass tourism arising in the second half of the 19th and the beginning of the 20th century, and the growing interest in active leisure activities are still a permanent element of our reality. Sociology treats tourism and travel as attributes of modernity. Featured types of tourists: the cognitive, interested in observing nature, culture, and also strangers; the integrative, striving to build relationships only with their own group of travellers; the task-oriented type, taking specific actions; and entertainment, professional and health tourists (Olkuśnik 2015: 12-14) - we can find them all at the beginning of the 20th century in the described articles from "Nasze Zdroje". It is interesting that the journal took care to keep a certain harmony in the presented content, without denying any of the motives for or ways of conducting tourism. Health care and the need to support spa treatment with physical activity came to the fore. Travel also enriched man spiritually, cognitive considerations were emphasized - contact with culture, monuments, and natural features. Articles in "Nasze Zdroje" mobilized readers to action, and propagated beliefs about the necessity of leaving the city and undertaking various forms of activity for both health and hygiene. Travel and treatment in Polish spas was shown as a form of patriotic duty, an activity that allowed for a partial breaking of the partition cordons.

\section{References}

Akademicki Klub Turystyczny we Lwowie (1911), "Nasze Zdroje”, 7: 81.

Akademicki Klub Turystyczny we Lwowie (1913a), “Nasza Turystyka”, 6: 70-71.

Akademicki Klub Turystyczny we Lwowie (1913b), “Nasza Turystyka”, 9: 35-36.

Bandrowski J. (1910) Polskie letniska, "Nasze Zdroje”, 16: 204-205.

Bednarz-Grzybek R. (2018) Wychowanie zdrowotne na łamach polskojęzycznych czasopism uzdrowiskowych (1844-1914), Lublin, Wydawnictwo Uniwersytetu Marii Curie-Skłodowskiej.

Dr K.K. (1911) W obronie naszych zdrojów, naszych gór!, "Nasze Zdroje”, 7: 78. 
Espe (1911) Przegląd zdrojowisk, “Nasze Zdroje”, 6: 71.

G.K. (1911) Przegląd zdrojowisk i uzdrowisk, “Nasze Zdroje”, 18: 235-236.

Gąsiorowski H. (1911) Kilka uwag na temat podniesienia ruchu turystycznego, "Nasze Zdroje", 1: 2-3.

Górski R. (1910) Lubień dawny i dzisiejszy, "Nasze Zdroje”, 11: 149-151.

Hemmerling K. (1911) Sporty zimowe na terenach Krynicy, "Nasze Zdroje”, 25: 317.

J.E. (1912) Z wycieczki młodzieży szkolnej, “Nasze Zdroje”, 13: 207-208.

Jak stworzyć ruch turystyczno-krajoznawczy w Galicji (1912) “Nasze Zdroje”, 2: 23-24.

Jarosiński A. (1910a) Notatki z wycieczek balneologiczno-turystycznych po kraju, "Nasze Zdroje", 7: 94-95.

Jarosiński A. (1910b) Notatki z wycieczek balneologiczno-turystycznych po kraju, "Nasze Zdroje", 14: 180-181.

Jarosiński A. (1910c) Notatki z wycieczek balneologiczno-turystycznych po kraju, "Nasze Zdroje", 15: 192-193.

Kęczkowska Z. (1912) Gdzie spędzić lato?, "Nasze Zdroje”, 13: 202-203.

Klimek W. (1910) Sporty a zdrojowiska, "Nasze Zdroje”, 1: 4.

Kolonie lecznicze polskie (1910), “Nasze Zdroje”, 11: 150.

Kozłowski S. (1912) O odżywianiu normalnem $w$ zakładzie leczniczym w Ojcowie, "Nasze Zdroje”, 8: 119.

Krajowy Zwiq̨zek Zdrojowisk i Uzdrowisk (1912) “Nasze Zdroje”, 12: 191.

Kronika turystyczna (1913a) "Nasza Turystyka”, 3: 12.

Kronika turystyczna (1913b) “Nasza Turystyka”, 7: 30.

Kronika turystyczna (1913c) “Nasza Turystyka”, 8: 34.

Kronika turystyczna (1914) “Nasze Zdroje i Nasza Turystka”, 1: 2.

Kubik W. (1912a) Piękno naszych zdrojowisk, "Nasze Zdroje”, 1912, 7: 115-116.

Kubik W. (1912b) Piękno naszych zdrojowisk, "Nasze Zdroje”, 1912, 9: 136-137. 
Łazarski T. (1912) Zdrojowiska i dzieci, "Nasze Zdroje”, 14: 219.

M.R . (1911) Projekty zdrojowisk na rok 1911. Ciechocinek, “Nasze Zdroje”, 1: 10.

Nasz Przewodnik po zdrojowiskach, miejscach klimatycznych i turystycznych (1912), "Nasze Zdroje", 21: 310-311.

Nasza turystyka (1912) “Nasze Zdroje”, 14: 218-219.

O kulturę śląskich Beskidów (1914) “Nasza Turystyka”, 1: 1.

Olkuśnik M. (2015) Wyjechać z miasta. Mieszkańcy Warszawy wobec podróży, turystyki i wypoczynku na przełomie XIX i XX wieku, Warszawa, Polskie Towarzystwo Historyczne Wydawnictwo Neriton.

Orłowicz M. (1912) Wycieczka medyków lwowskich po zdrojowiskach, "Nasze Zdroje", 15: 231-232.

Orłowicz M. (1913a) Co i jak zwiedzać w Galicji?, “Nasza Turystyka”, 10: 39-41.

Orłowicz M. (1913b) Konferencja turystyczna, "Nasza Turystyka”, 2: 6-7.

Polskie Towarzystwo Krajoznawcze we Lwowie (1912) “Nasze Zdroje”, 9: 143.

Polskie Towarzystwo Krajoznawcze w Warszawie (1913) “Nasza Turystyka”, 6: 21-22.

Przegląd zdrojowisk i uzdrowisk polskich (1910) “Nasze Zdroje”, 10: 125.

Przegląd zdrojowisk i uzdrowisk polskich (1912a) “Nasze Zdroje”, 13: 207.

Przegląd zdrojowisk i uzdrowisk polskich (1912b) “Nasze Zdroje”, 21: 311-312.

Rak L. (2010) Motywy uprawiania narciarstwa przez Polaków do 1914 r., "Prace Naukowe Akademii im. Jana Długosza w Częstochowie”, seria: Kultura Fizyczna, 9: 11-23.

Sekcja Turystyczna Krajowego Zwiq̨zku Zdrojowisk i Uzdrowisk (1912), “Nasze Zdroje", 10: 163.

Sokołowski A. (1913) Wakacje w kraju, "Nasze Zdroje i Nasza Turystyka", 15: 205-206.

Stępnik A. (2017) Turystyka w edukacji - spór o pojęcia, znaczenia, zastosowania in: Turystyka w edukacji historycznej i obywatelskiej, M. Ausz, J. Bugajska-Więcławska, A. Stępnik, D. Szewczuk (eds.), Lublin, Wydawnictwo Uniwersytetu Marii Curie-Skłodowskiej: 27-57. 
Szczepański T. (1911) Dyrektor szkoły handlowej w Włocławku, "Nasze Zdroje", 13: 163.

Szewczuk D. (2017) Z doświadczeń historycznych in: Turystyka w edukacji historycznej i obywatelskiej, M. Ausz, J. Bugajska-Więcławska, A. Stępnik, D. Szewczuk (eds.), Lublin, Wydawnictwo Uniwersytetu Marii Curie-Skłodowskiej: 147-164.

W sprawie kolonii wakacyjnych (1912) “Nasze Zdroje”, 12:194.

W.A. (1913) "Ziemia”, “Nasza Turystyka”, 7: 29.

W.F. (1912) Kilka słów w sprawie rozwoju turystyki i ruchu obcych w kraju, "Nasze Zdroje", 11: 184.

Wiadomości bieżące ((1911a) “Nasze Zdroje”, 10: 123.

Wiadomości bieżące (1911b) “Nasze Zdroje”, 24: 309-311.

Wiadomości bieżące (1912a) “Nasze Zdroje”, 1: 8.

Wiadomości bieżq̨ce (1912b) “Nasze Zdroje”, 5: 76.

Wiadomości bieżące (1912c) “Nasze Zdroje”, 6: 93.

Wiadomości bieżące (1912d) “Nasze Zdroje”, 10: 166-167.

Wiadomości bieżące (1912e) “Nasze Zdroje”, 18: 275.

Wiadomości bieżące (1912f) “Nasze Zdroje”, 20: 302.

Wiadomości bieżące (1912g) “Nasze Zdroje”, 21: 316.

Wiadomości bieżq̨ce (1913a) “Nasze Zdroje”, 1913, 1: 14.

Wiadomości bieżące (1913b) “Nasze Zdroje”, 1913, 2: 25.

Wiadomości bieżące (1913c) “Nasze Zdroje”, 1913, 3: 38-40.

Wiadomości bieżące (1913d) “Nasze Zdroje”, 1913, 7: 91.

Wiadomości bieżące (1913a) “Nasze Zdroje i Nasza Turystyka”, 7: 95.

Wiadomości bieżące (1913b) “Nasze Zdroje i Nasza Turystyka”, 12: 164.

Z nowym rokiem pracy (1913) “Nasze Zdroje i Nasza Turystyka”, 1: 1. 
Z ruchu towarzystw (1913) "Nasza Turystyka", 1: 1-4.

Z życia towarzystw (1913a) “Nasza Turystyka”, 3: 11.

Z życia towarzystw (1913b) “Nasza Turystyka”, 4: 15.

Z życia towarzystw (1913c) “Nasza Turystyka”, 7: 28.

Z życia towarzystw (1913d) “Nasza Turystyka”, 10: 42.

Zawody narciarskie w Sławsku (1913) “Nasza Turystyka”, 3: 12.

Zawody Tatrzańskiego Towarzystwa Narciarzy (1913) “Nasza Turystyka”, 4: 15.

Zwiq̨zek Polskich Towarzystw Turystycznych (1913) “Nasza Turystyka”, 8: 32. 